\title{
Pemberian Vaksin Formalin Killed Cell (FKC) Vibrio alginolitycus Untuk Meningkatkan Survival Rate (SR), Titer Antibodi Dan Fagositosis Leukosit Pada Kerapu Cantang (Epinephelus sp.) Setelah Uji Tantang Bakteri Vibrio alginolitycus
}

\author{
Administration Of Vaccine Formalin Killed Cell (FKC) Vibrio alginolyticus To Increase \\ Survival Rate (SR), Antibody Titre, And Phagocytic Leukocytes Cantang Grouper \\ (Epinephelus sp.) Against Bacteria Vibrio alginolitycus
}

Nurul Qomariyah $^{1^{*}}$, Hari Suprapto ${ }^{2}$ Sudarno $^{2}$

${ }^{1}$ Budidaya Perairan, Fakultas Perikanan dan Kelautan Universitas Airlangga, Surabaya 60115
${ }^{2}$ Departemen Manajemen Kesehatan Ikan dan Budidaya Perairan, Fakultas Perikanan dan Kelautan
Universitas Airlangga, Surabaya 60115
${ }^{*}$ nurulmukti1811@gmail.com

\begin{abstract}
Abstrak
Vaksinasi merupakan suatu upaya untuk menimbulkan ketahanan tubuh yang bersifat spesifik melalui pemberian vaksin. Vaksinasi digunakan untuk mencegah serangan penyakit infeksi serta efektif untuk mengontrol serangan penyakit ikan seperti bakteri $V$. alginolyticus. Pengamatan tingkat kelulushidupan (SR) dan pengukuran titer antibody merupakan pengukuran efektivitas vaksinasi, sedangkan tingkat kesehatan ikan dapat dilihat dari hematologi salah satunya adalah fagositosis leukosit. Tujuan dari penelitian ini Untuk mengetahui tingkat kelulushidupan, titer antibodi, dan indeks fagositosis leukosit benih ikan kerapu cantang yang divaksin dengan vaksin FKC bakteri Vibrio alginolyticus. Penelitian ini dilakukan di Balai Perikanan Budidaya Air Payau Situbondo, Jawa Timur. Penelitian ini menggunakan metode Rancangan Acak Lengkap dengan lima perlakuan dan tiga ulangan. Perlakuan yang digunakan adalah kontrol negatif, kontrol positif, 0,0125 mg/5 g BB ikan, 0,25 mg/ 5 g BB ikan, 0,5 mg/ 5 BB ikan. Analisis hasil menggunakan ANOVA dan dilanjutkan Uji Jarak Berganda Duncan. Hasil penelitian menunjukkan bahwa perlakuan pemberian vaksinasi memberikan pengaruh terhadap tingkat kelulushidupan (SR), titer antibody, dan indeks fagositosis benih ikan kerapu cantang. Jumlah tingkat kelulushidupan ikan kerapu cantang yang divaksinasi terbaik yaitu 70,0\%, titer antibodi yang divaksinasi terbaik yaitu 298,67, dan indeks fagositosis yang terbaik yaitu 52,67\%. Hasil penelitian dengan pemberian vaksin formalin killed cell (FKC) Vibrio alginolitycus dapat memberikan proteksi pada ikan dan penggunaan dosis yang berbeda mampu mempengaruhi tingkat kelulushidupan (SR), titer antibodi, dan indeks fagositosis.
\end{abstract}

Kata Kunci : Vaksin FKC, V.alginolyticus, Epinephelus sp. ,Titer antibodi, Fagositosis leukosit.

\begin{abstract}
Vaccination is an attempt to give-specific endurance through vaccine. Vaccination is used to prevent infectious diseases and effective to control fish diseases such as bacterial attack V. alginolyticus. Observations survival rate (SR) and measurement of antibody titre is a measure of the effectiveness of vaccination, while the level of health of the fish can be seen from the hematology one of which is phagocytic leukocytes. The purpose of this research was to determine the effect of the vaccine Formaldehyde Killed Cell (FKC) Vibrio alginolitycus to increase survival rate (SR), antibody titre, and phagocytic leucocytes cantang grouper (Epinephelus sp.) This research used a completely randomized design with five treatments and three replications. The treatment used is the negative control, the positive control, $0.0125 \mathrm{mg} / 5 \mathrm{~g}$ BB fish, $0.25 \mathrm{mg} / 5 \mathrm{~g}$ BB fish , $0.5 \mathrm{mg} / 5 \mathrm{BB}$ fish. Analysis of the results using ANOVA and Duncan's Multiple Range Test continued. The results showed that the treatment of vaccination impact the survival rate (SR), antibody titre, and phagocytosis index cantang grouper seed. Total survival rate, antibody titre, and the best phagocytosis index cantang grouper with consecutive values as follows $70,0 \%, 298,67$, and 52,67\%. This research that used the vaccine formaldehyde killed cells (FKC) Vibrio alginolitycus can provide protection to the fish and the use of different doses capable of affecting the survival rate (SR), antibody titre, and the index of phagocytosis.
\end{abstract}

Keywords: Vaccines FKC, V.alginolyticus, Epinephelus sp. , Antibody titre, Phagocytic leukocytes.

15 |J I P K Vol.9 No.1, A prill 2017 Diterima/submitted:25 Desember 2016 Disetujui/accepted:9 M a ret 2017 


\section{PENDAHULUAN}

Ikan kerapu yang banyak diminati oleh konsumen di pasar mancanegara, salah satunya adalah ikan kerapu Cantang (Epinephelus sp.). Pada tahun 2010 pertama kali di Indonesia diproduksi ikan kerapu cantang hasil hibridisasi antara ikan Kerapu Macan betina dan ikan Kerapu Kertang jantan di Balai Pengembangan Budidaya Air Payau (BPBAP) Situbondo (Nurhayati $d k k .$, 2014). Kerapu cantang saat ini merupakan komoditas ekspor yang sangat diminati oleh petani ikan untuk dibudidayakan karena mempunyai nilai ekonomis tinggi. Namun dalam perkembangan budidaya ikan kerapu masih dihadapkan pada beberapa masalah. Salah satu masalah budidaya ikan kerapu adalah penyakit yang disebabkan oleh bakteri patogen (Lestari dkk, 2012). Jenis penyakit yang sering terjadi yaitu disebabkan oleh bakteri dari genus Vibrio sp (Fandina dkk., 2012). Lestari dkk (2012) menyatakan bahwa bakteri $V$. alginolyticus merupakan bakteri yang paling sering menginfeksi ikan kerapu pada saat dibudidaya dan dapat menyebabkan kematian masal sehingga menimbulkan kerugian cukup besar bagi petani.

Alternatif penanggulangan penyakit bakterial biasanya dengan cara vaksinasi, Vaksinasi merupakan suatu upaya untuk menimbulkan ketahanan tubuh yang bersifat spesifik melalui pemberian vaksin (Alifuddin, 2002). Syarat dari suatu vaksin harus bersifat immunogen yaitu harus dapat merangsang dalam pembentukan antibodi (Noerbaeti dkk., 2009). Hasil penelitian Kristanto (2013) menunujukkan bahwa survival rate ikan yang divaksin lebih tinggi dibandingkan ikan yang tidak divaksin. Vaksinasi dapat meningkatkan fungsi fagositosis dari leukosit yang berperan penting untuk melawan infeksi bakteri melalui rangsangan imunogenik dari vaksin, salah satu vaksin tersebut adalah vaksin Formalin Killed Cell (FKC) yang sering digunakan dalam bidang perikanan.

\section{METODOLOGI PENELITIAN}

Penelitian dilakukan di Laboratorium Balai Perikanan Budidaya Air Payau (BPBAP) Pecaron, Situbondo pada bulan Mei-September 2016.

\section{Persiapan Ikan Uji}

Benih ikan kerapu cantang berukuran 7-9 cm dengan berat badan 8,85 g, dimasukkan ke dalam 15 akuarium yang telah siap secara acak. Masing-masing akuarium diisi benih ikan kerapu cantang sebanyak 10 ekor. Berdasarkan penelitian Kristanto (2013) benih ikan kerapu cantang diadaptasikan selama tiga hari yang

16|JI P K Vol.9 No.1, A pril 2017 Diterima/submitted:25 Desember 2016 Disetujui/accepted:9 Maret 2017 
bertujuan supaya benih kerapu cantang tidak stres dan mati akibat perubahan media.

\section{Kultur Bakteri Vibrio alginolyticus}

Isolat bakteri $V$. alginolyticus didapat dari Balai Perikanan Budidaya Air Payau (BPBAP) Situbondo. Kultur bakteri dilakukan dengan menggunakan media TSB yang dimasukkan ke dalam labu erlenmeyer. Pembuatan media kultur dibutuhkan 15 g TSB dan 10 g NaCl yang dicampur dengan $500 \mathrm{ml}$ aquadest dan diaduk hingga larut. Labu erlenmeyer kemudian ditutup dengan aluminium foil dan diautoclave dengan suhu $121^{\circ} \mathrm{C}$, tekanan 1 atm selama 15 menit supaya media steril dari patogen lain (Fandina, 2012). Media yang telah disterilkan diletakkan pada suhu ruang hingga dingin. Selanjutnya isolat bakteri Vibrio alginolyticus dimasukkan atau dituangkan pada media sebanyak $1 \mathrm{ml}$. Labu erlenmeyer ditutup kembali dengan aluminium foil dan diinkubasi pada suhu ruang dalam waktu 24-48 jam (Suprapto, 2009).

\section{Pembuatan vaksin Formalin Killed Cell}

\section{(FKC) Vibrio alginolyticus}

Media TSB disentrifus dengan kecepatan 4000 rpm selama 10 menit. Supernatan dibuang kemudian ditambahkan PBS sebanyak $40 \mathrm{ml}$ dan disentrifus lagi pada kecepatan yang sama. Suprapto (2005) mengatakan bahwa proses pembuangan supernatan dan penambahan PBS dilakukan sebanyak tiga kali supaya didapatkan endapan bakteri yang bersih dari media TSB. Penambahan PBS sebanyak 25 ml pada bakteri yang telah bersih dari media TSB dan diinaktifkan selama 18-24 jam dengan menggunakan formalin sebanyak 2\% (Suprapto, 2009). Bakteri yang telah diformalin diinkubasi pada suhu $25^{\circ} \mathrm{C}$ selama 72 jam, selanjutnya bakteri dicuci menggunakan PBS sebanyak satu kali dengan cara disentrifus dengan kecepatan 3000 rpm selama 15 menit dan disimpan pada suhu $4^{\circ} \mathrm{C}$ (Suprapto, 2005)

\section{Uji Viabilitas}

Uji viabilitas vaksin dilakukan pada media TCBSA (Thiosulfat Citrate Bilesalt Sucrose Agar). Vaksin aman digunakan jika pada media kultur tersebut tidak terjadi pertumbuhan bakteri (Alifuddin, 2002)

\section{Mikrokapsul Vaksin Menggunakan}

\section{Alginat}

Proses pembuatan vaksin mikrokapsul dilakukan dengan cara menyemprotkan suspensi FKC dan alginat ke dalam larutan $\mathrm{CaCl} 2$ dengan perbandingan 1:6 v/v. Mikrokapsul yang terbentuk kemudian dicuci menggunakan 
aquadest dengan cara disentrifus. Supernatan yang terbentuk ditampung di dalam botol, kemudian ditambah aquadest dan disentrifus lagi. Pencucian dilakukan sebanyak tiga kali hingga mikrokapsul bersih dari larutan $\mathrm{CaCl} 2$. Setelah proses pencucian, mikrokapsul dikeringkan dengan cara diangin-anginkan dalam suhu ruang selama kurang lebih 3-7 hari. Mikrokapsul yang telah kering kemudian disimpan dalam botol steril (Ain et al., 2003).

\section{Pemberian Vaksin Formalin Killed Cell} (FKC)

Pemberian vaksin dilakukan dengan tiga dosis berbeda, yaitu pada perlakuan P3 $(0,0125 \quad \mathrm{mg} / 5 \quad \mathrm{~g} \quad \mathrm{BB}$ ikan/hari), P4 (0,025 mg/5 g BB ikan/hari) dan P5 (0,05 mg/5 g BB ikan/hari), pakan diberikan 5\% dari biomassa ikan per hari (Fandina $d k k$, 2012). Pada perlakuan P1 (kontrol negatif) dan P2 (kontrol positif) tidak ada pemberian vaksin, namun pada P1 tidak diuji tantang, sedangkan P2 diuji tantang menggunakan bakteri V.alginolyticus. Berdasarkan penelitian Kristanto (2013) Pemberian vaksin dilakukan selama tujuh hari, dengan pemberian pakan dua kali sehari.

\section{Uji Tantang dengan Bakteri Vibrio} alginolyticus
Uji tantang dilakukan setelah 7 hari pemberian vaksin pada P3 (0,0125 mg/5 g BB ikan/hari), P4 (0,025 mg/5 g BB ikan/hari) dan P5 (0,05 mg/5 g BB ikan/hari), dan P2 (Kontrol Positif), benih kerapu cantang diuji tantang dengan cara menginfeksikan bakteri sebanyak $10^{8} \mathrm{CFU} / \mathrm{ml}$ (Suprapto, 2009), Bahan uji diamati selama tujuh hari untuk mengetahui mortalitasnya.

\section{Penghitungan Kelulushidupan (Survival} Rate / SR)

Kelulushidupan merupakan perbandingan antara jumlah individu yang hidup pada akhir percobaan dengan jumlah individu yang masih hidup pada awal percobaan (Kristanto, 2013).

$$
\text { Menurut Aprilia }
$$

Penghitungan kelulushidupan

menggunakan rumus:

$\mathrm{SR}=\frac{\mathrm{Nt}}{\mathrm{N} 0} \times 100 \%$

Keterangan:

$\mathrm{SR}=$ Kelulushidupan benih ikan kerapu (\%)

$\mathrm{Nt}=$ Jumlah benih ikan pada akhir penelitian

N0 = Jumlah benih ikan pada awal penelitian

\section{Penghitungan Titer Antibodi}

Titer antibodi yang berasal dari serum ikan kerapu cantang yang telah divaksinasi ditentukan dengan uji 
aglutinasi. Prosedur uji aglutinasi yang digunakan menurut Suprapto (2009), yaitu $25 \mu \mathrm{l}$ PBS dimasukkan ke dalam microplate U pada lubang 1 sampai 12. Antiserum sebanyak $25 \mu \mathrm{l}$ selanjutnya dimasukkan pada lubang 1 dan diaduk hingga homogen, selanjutnya dilakukan pengenceran dengan cara mengambil $25 \mu \mathrm{l}$ menggunakan mikropipet dari lubang 1 ke lubang 2 sampai lubang 11. Satu tetes antigen $(25 \mu \mathrm{l})$ dimasukkan pada lubang 112. Microplate U selanjutnya digoyang selama 5 menit dan diinkubasi pada suhu $37^{\circ} \mathrm{C}$ selama 2 jam, kemudian pembacaan titer antibody dengan mengamati adanya gumpalan. Kontrol dilakukan sama dengan di atas, antiserum yang digunakan diganti dengan PBS.

\section{Uji fagositosis Leukosit secara in vitro}

Sebanyak $50 \mu$ darah dimasukkan ke dalam mikrotiter plate, ditambahkan 50 $\mu 1$ suspensi Vibrio alginolyticus dalam PBS $\left(10^{8} \mathrm{sel} / \mathrm{ml}\right)$, dihomogenkan dan diinkubasi dalam suhu ruang selama 20 menit. Sebanyak $5 \mu$ dibuat sediaan ulas darah dan dikering-udarakan. Selanjutnya difiksasi dengan metanol selama 5 menit dan dikeringkan. Direndam dalam pewarna Giemsa selama 15 menit dan dicuci dengan air mengalir dan dikeringkan dengan tisu. Diamati di bawah mikroskop dengan perbesaran 1000x. Jumlah sel yang menunjukkan proses fagositosis dihitung dari 100 sel fagosit yang teramati (Maswan, 2009).

Setiawan dkk (2012) mengatakan untuk menghitung indeks fagositosis menggunakan rumus sebagai berikut:

$\begin{aligned} & \text { Indeks Fagositosis } \\ & 100 \%\end{aligned}=\frac{\sum \mathrm{PA}}{100 \mathrm{~PB}} \mathrm{x}$

Keterangan:

$\mathrm{PI}=$ Indeks Fagositosis (\%)

$\sum \mathrm{P}=$ Jumlah sel darah putih yang memfagosit

$\mathrm{PB}=$ sel darah putih yang diamati

\section{Pengukuran Kualitas Air}

Kualitas air merupakan faktor penting dalam pemeliharaan benih ikan kerapu (Kristanto, 2013). Pengukuran kualitas air dilakukan supaya kualitas air terpantau dan layak bagi kegiatan pembenihan ikan. Kualitas Air yang diukur meliputi Suhu, Salinitas, DO dan $\mathrm{pH}$.

\section{Parameter Penelitian}

Parameter utama dalam penelitian ini adalah pengukuran SR (Survival rate), Titer antibody, dan fagositosis leukosit ikan (sebelum vaksinasi, setelah vaksinasi, setelah uji tantang). Parameter pendukung pada penelitian ini berupa kualitas air seperti suhu, oksigen terlarut, dan $\mathrm{pH}$ selama penelitian.

\section{Analisis Data}

Data yang diperoleh meliputi nilai SR (Survival rate), Titer antibody, dan 
fagositosis leukosit ikan (sebelum vaksinasi, setelah vaksinasi, setelah uji tantang) dalam bentuk tabel kemudian dianalisis. Uji statistik dengan menggunakan ANOVA (Analysis of Variance) untuk mengetahui pengaruh pemberian vaksin formalin killed cell (FKC) V. alginolyticus terhadap SR (Survival rate), Titer antibodi, dan fagositosis leukosit ikan kerapu cantang. Uji lanjut dilakukan dengan Uji Jarak Berganda Duncan dengan taraf signifikansi sebesar 5\% untuk mengetahui perlakuan yang paling baik (Kusriningrum, 2008).
HASIL DAN PEMBAHASAN

Jumlah Tingkat Kelulushidupan

(Survival Rate)

Berdasarkan uji ANOVA diperoleh hasil penelitian tentang jumlah tingkat kelulushidupan ikan kerapu cantang yang menunjukkan bahwa terdapat perbedaan yang nyata antar perlakuan. Tahap berikutnya dilakukan uji Jarak Berganda Duncan dengan taraf signifikansi 5\%. Penghitungan jumlah tingkat kelulushidupan ikan kerapu cantang dapat dilihat pada Tabel 1.

Tabel 1. Hasil Kelulushidupan ( Survival Rate/ SR) dan SD ( $\bar{x} \pm$ SD) Ikan Kerapu Cantang

\begin{tabular}{lc}
\hline Perlakuan & Rata-Rata \pm SD \\
\hline P1 & $90,00^{\mathrm{a}} \pm 0,52$ \\
P1 & $13,33 \mathrm{~d} \pm 0,75$ \\
P2 & $36,67 \mathrm{c} \pm 0,48$ \\
P3 & $63,33 \mathrm{~b} \pm 0,35$ \\
P4 & $70,00^{\mathrm{b}} \pm 0,59$ \\
\hline
\end{tabular}

Keterangan : ${ }^{\text {a,b,c,d }}$ Superskrip yang berbeda pada baris yang sama menunjukkan perbedaan yang nyata $(\mathrm{p}<0,05)$,

P1 : Kontrol tanpa pemberian vaksin dan tanpa dilakukan uji tantang

P2 : Kontrol tanpa pemberian vaksin dan dilakukan uji tantang 
Tabel 2. Titer Antibodi Ikan Kerapu Cantang

Perlakuan

Pengukuran Titer Antibodi

P1 (Kontrol Negatif)

P2 (Kontrol Positif)

P3 (0.0125 mg/5 g BB ikan)

P4 (0.025 mg/5 g BB ikan)

P5 (0.05 mg/5 g BB ikan)

\begin{tabular}{clc} 
Sebelum Vaksinasi & H+ Vaksinasi & H+ Uji Tantang \\
\hline $4,00^{\mathrm{a}} \pm 0,00$ & $5,33^{\mathrm{c}} \pm 0,173$ & $5,33^{\mathrm{b}} \pm 0,173$ \\
$5,33^{\mathrm{a}} \pm 0,173$ & $5,33^{\mathrm{c}} \pm 0,173$ & $4,00^{\mathrm{b}} \pm 0,00$ \\
$5,33^{\mathrm{a}} \pm 0,14$ & $2,67^{\mathrm{bc}} \pm 0,1733$ & $7,33^{\mathrm{b}} \pm 0,30$ \\
$6,67^{\mathrm{a}} \pm 0,173$ & $106,67^{\mathrm{b}} \pm 0,173$ & $85,33^{\mathrm{b}} \pm 0,173$ \\
$5,33^{\mathrm{a}} \pm 0,173$ & $213,33^{\mathrm{a}} \pm 0,173$ & $298,67^{\mathrm{a}} \pm 0,30$ \\
\hline
\end{tabular}

Keterangan : ${ }^{\text {a,b,c,d }}$ Superskrip yang berbeda pada baris yang sama menunjukkan perbedaan yang nyata $(\mathrm{p}<0,05)$,

P1 : Kontrol tanpa pemberian vaksin dan tanpa dilakukan uji tantang

P2 : Kontrol tanpa pemberian vaksin dan dilakukan uji tantang

Pada uji jarak berganda Duncan menunjukkan bahwa pemberian vaksin formalin killed cell (FKC) V. alginolyticus terhadap tingkat kelulushidupan (SR) benih ikan kerapu cantang menghasilkan rata-rata persentase tertinggi pada perlakuan P5 (70,0\%) yang tidak berbeda nyata dengan perlakuan P4 (63,3\%). Kristanto (2013) menyatakan hasil penelitiannya bahwa tingkat kelulushidupan kelompok ikan yang divaksin lebih tinggi dibanding kontrol. Hal ini disebabkan ikan yang divaksin mampu memproduksi antibodi lebih banyak.

\section{Pengukuran Titer Antibodi Benih Ikan}

\section{Kerapu Cantang}

Alifuddin (2002) mengatakan bahwa pengukuran efektivitas vaksin dapat dilakukan dengan cara pengukuran titer antibodi, dapat dilihat besarnya titer antibodi yang terbentuk. Penghitungan titer antibodi ikan kerapu cantang dapat dilihat pada Tabel 2.

Hasil pengukuran antibodi pada awal penelitian menunjukkan nilai antara 4,00-6,67. Dengan demikian, ikan uji yang digunakan diduga pernah terpapar V.alginolyticus, sebab Irianto (2005) mengatakan bahwa adanya titer antibodi pada ikan sebelum vaksinansi berasal dari bawaan induknya (innate) yang pernah terpapar bakteri tersebut yang diturunkan secara genetik.

$$
\text { Verma and Agarwal (2005) }
$$
mengatakan peningkatan titer antibodi disebabkan karena ketika terpapar antigen yang sama pada saat uji tantang, respon imun terjadi lebih cepat dengan memproduksi antibodi lebih tinggi 
dibandingkan infeksi pertama. Berdasarkan data pengukuran titer antibodi dari vaksin formalin killed ell (FKC) V. alginolitycus menunjukkan bahwa penggunaan vaksin tersebut memiliki respon positif bila dilihat dari kadar antibodinya. Saat uji tantang, benih ikan kerapu cantang yang memiliki antibodi lebih mampu membantu tubuh untuk mengeliminasi patogen yang menginfeksi sehingga mortalitas dapat diminimalisir. Rata-rata persentase tingkat kelulushidupan benih ikan kerapu cantang yang divaksinasi pada perlakuan P4, dan P5 termasuk dalam tingkatan baik. Hal ini sesuai dengan pernyataan Suprapto (2009), vaksinasi yang berhasil minimal SR pada ikan yang divaksin adalah 60 persen. Antibodi terbentuk akibat interaksi antigen yang masuk dalam tubuh dengan salah satu leukosit (limfosit).

\section{Indeks fagositosis secara in vitro}

Peningkatan total leukosit maupun persentase jenis darah leukosit dapat dilihat dari persentase indeks fagositik (Maswan, 2009). Hasil pengamatan rata-rata persentase indeks fagositosis ikan kerapu cantang sebelum vaksinasi menunjukkan nilai indeks fagositosis yang tidak berbeda nyata pada tiap perlakuan, rata-rata persentase indeks fagositosis antara 31,33$32,67$.

Rata-rata persentase indeks fagositosis ikan kerapu cantang setelah vaksinasi pada tiap perlakuan menunjukkan nilai indeks fagositosis diantaranya P1, P2 dan P3 tidak berbeda nyata, perlakuan P4 berbeda nyata dengan semua perlakuan, begitu juga P5 berbeda nyata dengan semua perlakuan termasuk $\mathrm{P} 4$, dan merupakan rata-rata persentase

Tabel 2. Rata-Rata Indeks Fagositosis Ikan Kerapu Cantang

Perlakuan

P1 (Kontrol Negatif)

P2 (Kontrol Positif)

P3 (0.0125 mg/5 g BB ikan)

P5 (0.05 mg/5 g BB ikan)
P4 (0.025 mg/5 g BB ikan)

Pengukuran Titer Antibodi

$$
\text { Sebelum Vaksinasi } \quad \mathrm{H}+\text { Vaksinasi } \quad \mathrm{H}+\text { Uji Tantang }
$$

\begin{tabular}{lll}
$32,33^{\mathrm{a}} \pm 0,133$ & $32,67^{\mathrm{c}} \pm 0,221$ & $34,00^{\mathrm{c}} \pm 0,171$ \\
$32,67^{\mathrm{a}} \pm 0,10$ & $34,33^{\mathrm{c}} \pm 0,049$ & $27,67^{\mathrm{c}} \pm 0,196$ \\
$32,00^{\mathrm{a}} \pm 0,176$ & $34,33^{\mathrm{c}} \pm 0,099$ & $32,67^{\mathrm{c}} \pm 0,100$ \\
$31,33^{\mathrm{a}} \pm 0,103$ & $53,33^{\mathrm{b}} \pm 0,143$ & $42,67^{\mathrm{b}} \pm 0,178$ \\
$32,33^{\mathrm{a}} \pm 0,133$ & $59,67^{\mathrm{a}} \pm 0,991$ & $52,67^{\mathrm{a}} \pm 0,450$ \\
\hline
\end{tabular}

Keterangan : ${ }^{\mathrm{a}, \mathrm{b}, \mathrm{c}, \mathrm{d}}$ Superskrip yang berbeda pada baris yang sama menunjukkan perbedaan yang nyata $(\mathrm{p}<0,05)$,

P1 : Kontrol tanpa pemberian vaksin dan tanpa dilakukan uji tantang

P2 : Kontrol tanpa pemberian vaksin dan dilakukan uji tantang 
indeks fagositosis tertinggi. Hal ini menunjukkan terjadi peningkatan kekebalan tubuh, sebab nilai indeks fagositik yang tinggi pada perlakuan vaksinasi menggambarkan bahwa proses fagositosis yang terjadi dengan cepat berkontribusi dalam mekanisme penyajian antigen (antigen presenting cells) untuk merangsang respon sel limfosit (Santika, 2007).

Nilai indeks fagositosis setelah uji tantang pada semua perlakuan mengalami penurunan, kecuali pada P1 karena merupakan perlakuan kontrol negatif yang tidak diuji tantang. Hal ini sesuai dengan pernyataan Taukid dkk (2010) bahwa sel fagosit belum terdiferensiasi sempurna akibat sel tersebut telah digunakan dalam pertahanan tubuh ikan saat uji tantang.

\section{Kualitas Air Pemeliharaan Benih Ikan}

\section{Kerapu Cantang}

Parameter kualitas air yang diukur selama penelitian adalah suhu, derajat keasaman $(\mathrm{pH})$, salinitas dan oksigen terlarut. Pengukuran kualitas air dilakukan tiga hari sekali pada pagi dan sore hari sebelum pemberian pakan pada ikan. Data rata-rata pengukuran kualitas air pada tiap perlakuan dapat dilihat pada Tabel 5.

Pengukuran kualitas air selama penelitian menunjukkan bahwa kondisi kualitas air pada akuarium dalam kondisi normal, artinya kondisi kualitas air tersebut baik untuk pemeliharaan ikan. Hal ini sesuai dengan Aprilia (2008) yang mengatakan bahwa kualitas air yang cocok untuk pertumbuhan dan budidaya ikan kerapu meliputi suhu air berkisar antara 28-32 ${ }^{\circ} \mathrm{C}$, Disolved Oxygen (DO) lebih dari 5 ppm, dan pH antara 6,5-9 dan salinitas

Tabel 5. Data rata-rata pengukuran kualitas air pada tiap perlakuan

Perlakuan

\begin{tabular}{|c|c|c|c|c|c|c|c|c|}
\hline \multirow[t]{2}{*}{ 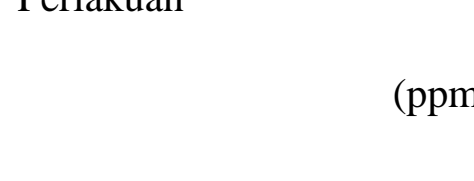 } & \multicolumn{2}{|c|}{ Suhu $\left(C^{0}\right)$} & & \multicolumn{2}{|c|}{ Salinitas (ppt) } & \multicolumn{2}{|c|}{ Oksigen Terlarut } \\
\hline & Pagi & Sore & Pagi & Sore & Pagi & Sore & Pagi & Sore \\
\hline P1 (Kontrol Negatif) & 28,1 & 28,2 & 8,26 & 8,21 & 34,2 & 34,2 & 3,90 & 3,16 \\
\hline P2 (Kontrol Positif) & 28,0 & 28,3 & 8,24 & 8,18 & 34,2 & 34,3 & 3,90 & 3,06 \\
\hline P3 (0,0125 mg/ 5 g BB ikan) & 28,0 & 28,1 & 8,23 & 8,17 & 35,0 & 34,9 & 4,06 & 3,30 \\
\hline P4 (0,025 mg/ 5 g BB ikan) & 28,2 & 28,4 & 8,20 & 8,17 & 35,0 & 35,0 & 4,00 & 3,10 \\
\hline P5 (0,05 mg/ 5 g BB ikan) & 28,2 & 28,2 & 8,15 & 8,09 & 34,4 & 34,2 & 3,94 & 3,18 \\
\hline
\end{tabular}

Keterangan:

P1 : Kontrol tanpa pemberian vaksin dan tanpa dilakukan uji tantang

P2 : Kontrol tanpa pemberian vaksin dan dilakukan uji tantang Diterima/submitted:25 D e sem b e r 2016 Disetujui/accepted:9 M a ret 2017 
antara 30-35 ppt (Haryadi, 2003).

\section{KESIMPULAN DAN SARAN}

Perlakuan yang memberikan hasil terbaik pada pemberian vaksin formalin killed cell (FKC) V. alginolyticus terhadap tingkat kelulushidupan, titer antibodi dan indeks fagositosis leukosit ikan kerapu cantang adalah P5 yaitu dengan dosis (0,05 mg). Perlu dilakukan penelitian lebih lanjut dengan penggunaan dosis yang berbeda pada penggunaan vaksin Formalin Killed Cell (FKC) V. alginolyticus dalam upaya penanggulangan vibriosis pada budidaya secara masal.

\section{DAFTAR PUSTAKA}

Ain, Q. S, Sharma, G. K. Khuller and S, K. Garg. 2003. Alginat-based Oral Drug Delivery System For Tuberculosis: Pharmacokinetics and Therapeutic Effect. Departements of Biochemistry and Pharmacology, Postraduate Insitute of Medical Education and Research, Chandigarh. India. Hal 8.

Alifuddin, M. 2002. Imunostimulasi Pada Hewn Akuatik. Jurusan Budidaya Perairan, Fakultas Perikanan dan Ilmu Kelautan Institut Pertanian Bogor, Kampus Darmaga, Bogor 16680, Indonesia. Hal 89-90.

Fandina, N.S. S, Hari dan Kismiyati. 2012. Vaksinasi Mikrokapsul Polivalen Vibrio Alginolyticus dan Vibrio Parahaemolyticus Pada Benih Ikan Kerapu Tikus (Cromileptes Altivelis). Jurnal Ilmiah Perikanan dan Kelautan. Fakultas Perikanan dan Kelautan Universitas Airlangga, Surabaya. 10 hal.

Kristanto, R. B. 2013. Respon Imun Dan Tingkat Kelulushidupan Benih Ikan Kerapu Tikus Yang Divaksin Secara Oral Dengan Mikrokapsul FKC Bakteri Vibrio alginolyticus Menggunakan Alginat Terhadap Infeksi Vibrio algynolyticus. Skripsi. Fakultas Perikanan Dan Kelautan Universitas Airlangga. Surabaya.

Kusriningrum. 2012. Perancagan Percobaan.Universitas Airlangga. Surabaya

Maswan, N.A. 2009. Pengujian Efektivitas Dosis Vaksin Dna Dan Korelasinya Terhadap Parameter Hematologi Secara Kuantitatif. Skripsi. Fakultas Perikanan Dan Ilmu Kelautan Institut Pertanian Bogor. Hal 21

Noerbaeti, E. H, M. Lutfi. Istiana. Syarifuddin. 2009. Pembuatan Vaksin Sederhana Dalam Mengatasi Serangan Bakteri Vibrio. Laporan Kegiatan Perekayasaan. Direktorat Jenderal Perikanan Budidaya. Balai Budiaya Laut Ambon.

Nurhayati, K. S, Endang. S, E. Rahayu. 2014. Identifiksi dan Prevalensi Ektoparasit Pada Ikan Kerapu Cantang (Ephinephelus Fuscoguttatus-Lanceolatus) Hasil Budidaya Keramba Jaring Apung (Kja) Di Bpbap Situbondo Dan Gundil Situbondo. Universitas Negeri Malang.

Lestari, E.P. Feliatra dan Y, Dessy. 2012. Uji Efektifitas Bakteri Asam Laktat Dalam Mengatasi Vibrio Alginolyticus Pada Ikan Kerapu Macan (Epinephelus fuscoguttatus). 